\title{
Climate panel must adapt to survive
}

\section{Review recommends better governance and transparency for the IPCC in the face of more public scrutiny.}

A long-awaited report has recommended an overhaul of the Intergovernmental Panel on Climate Change (IPCC). The proposals were met with a largely favourable response from climate researchers who are eager to move on after the media scandals and credibility challenges that have rocked the United Nations body during the past nine months.

Released on 30 August, the recommendations are the product of an independent review - commissioned by the IPCC and the $\mathrm{UN}$ - that looked in detail at how the IPCC conducts its business. In the 100-page report, the Amsterdam-based InterAcademy Council, which represents the world's science academies, recognizes that much of the IPCC's work is done by a throng of volunteer researchers who serve on the IPCC's various committees and working groups. However, the report recommends that the IPCC follow the organizational model adopted by corporations and universities and appoint a full-time executive director, who would manage daily operations and communications while reporting to an independent board of directors.

The report also made recommendations to bolster the IPCC's science reviews, to establish formal guidelines on reporting conflicts of interest for IPCC authors, review editors, staff and leadership, and to improve communications with the public and media.

"So much of the IPCC is just run on volunteer labour, and at a certain point for an effort this important and this complex, you simply need more dedicated bodies," says Linda Mearns, a senior scientist at the National Center for Atmospheric Research in Boulder, Colorado.

Founded in 1988, the IPCC's
"For an effort this important and this complex, you simply need more dedicated bodies."

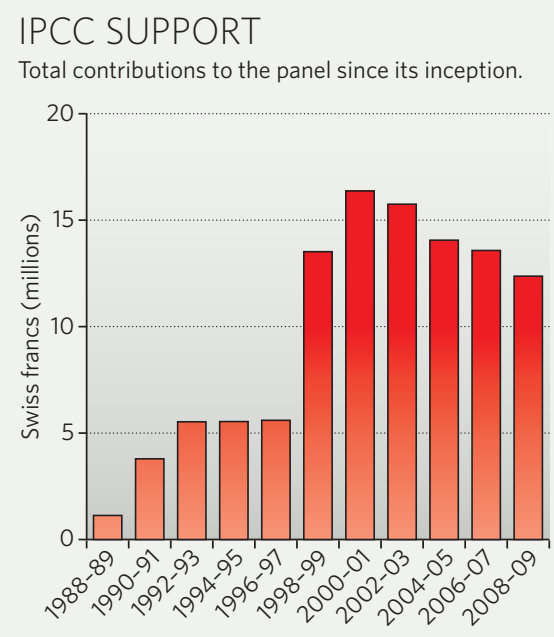

successes, both in terms of assessing the science of climate change and garnering support from governments around the world. "But fundamental changes are necessary to ensure its continued success," Shapiro says.

The controversies began last November, just before the climate conference in Copenhagen, when more than 1,000 private e-mails were leaked from the University of East Anglia in Norwich, UK. Allegations of errors in the 2007 IPCC fourth assessment report surfaced shortly afterwards, all focused on the analysis by Working Group II of the potential impacts of global warming. The IPCC corrected a controversial statement that Himalayan glaciers might disappear by 2035, but subsequent reviews have upheld the core science behind global warming.

The review panel identified task of providing climate information to the UN has grown in complexity - along with the overall size of its annual budget, which is underwritten by member nations (see chart).

The IPCC's chairman, Rajendra Pachauri, says that the review bolsters the IPCC's reputation and demonstrates that the science it provides is fundamentally sound. "My hope is that the accumulation of so many investigations into climate science in such a short period of time will strengthen public confidence so that we can move forward," he says.

Harold Shapiro, a former president of Princeton University, New Jersey, who chaired the review panel, credited the IPCC with enormous various problems with the way scientific uncertainty was handled in the last report. Shapiro says that the second working group's summary for policy-makers assigned "high confidence" - a quantitative measure that equates to $90 \%$ confidence - to statements for which there is little evidence. For example, the suggestion that the cost of adaptation to sea-level rise "could amount to at least $5-10 \%$ of gross domestic product", would have been better stated using qualitative language.

The report recommended that the IPCC strengthen its science-review process by encouraging review editors to use their existing authority to ensure that comments from reviewers are "adequately considered" when drafting assessments. The panel suggested that editors and authors could work together to rank reviewer's comments on the assessments to help manage the huge workload (drafts of the last assessment received 90,000 comments). Procedures must also be clarified for using and labelling 'grey literature' that has not been peer reviewed, such as reports by government agencies and advocacy groups.

Jay Gulledge, a senior scientist at the Pew Center on Global Climate Change in Arlington, Virginia, says that the report provides a solid set of recommendations that would move the IPCC forward. However, he says that the document glosses over the complex issue of evaluating and communicating risks, which is what policy-makers and the public ultimately want to understand. Although the IPCC has done a great job of advancing the science, he says, "I don't think it has done very much at all to advance society's understanding of the risks".

The recent controversies have also constituted the first challenge to Pachauri's leadership. Re-elected in 2008 to head the fifth assessment report, he was accused of ignoring early warnings as the errors scandal built up. Subsequent claims were made about improper financial ties to companies including Credit Suisse and Toyota. Pachauri says that any money he earned advising such companies went to support the Energy and Resources Institute (TERI), a non-profit organization that he heads in New Delhi. That explanation was proved correct last week in an independent audit commissioned by TERI and conducted by consulting firm KPMG, headquartered in Amstelveen in the Netherlands.

Under the proposed management structure, the IPCC chairman would lead a board composed of not just IPCC leaders but members from outside the climate community. The review panel also suggested that all leadership positions should be changed after every assessment report to inject fresh thinking into the process, raising further questions about Pachauri's second six-year term as IPCC chairman.

Pachauri says that decision will rest with the governments that sponsor the IPCC, which will discuss the report at their next meeting in Busan, South Korea, in mid-October. "It is for them to decide when they want to implement the recommendations and which ones they want to implement," he says.

Jeff Tollefson 